RASMUSSEN, D. I. (1970). Biochemical polymorphisms and genetic structure in populations of Peromyscus. Pp. 335-49 in Variation in Mammal Populations (Ed. J. R. Berry \& H. N. Southern). Academic Press, London, U.K.: xvi +403 pp., illustr.

REES, W. A. (1978). Do the dams spell disaster for the Kafue Lechwe? Oryx, 14 (3), pp. 231-5.

SCHMITT, L. H. (1978). Genetic variation in isolated populations of the Australian Bushrat, Rattus fuscipes. Evolution, 32 (1), pp. 1-14.

SCHULL, W. J., NAGANO, H., YAMAMOTO, M. \& KOMATSU, I. (1970). The effect of parental consanguinity and inbreeding in Hirado, Japan, I: Stillbirths and pre-reproductive mortality. Am. J. Hum. Genet., 22, pp. 239-62.

SCHULL, W. J. \& NEEL, J. V. (1965). The Effects of Inbreeding on Japanese Children. Harper \& Row, New York, N.Y.: xii +419 pp., illustr.

SCHULL, W. J. \& NEEL, J. V. (1966). Some further observations on the effects of inbreeding on mortality in Kure, Japan. Am. J. Hum, Genet., 18, pp. 144-52.

SELANDER, R. K. (1970a). Biochemical polymorphism in populations of the House Mouse and Old Field Mouse. Pp. 73-91 in Variation in Mammal Populations (Ed. R. J. Berry \& H. N. Southern). Academic Press, London, U.K.: xvi + 403 pp., illustr.

SELANDER, R. K. (1970b). Behavior and genetic variation in natural populations. Am. Zool., 10, pp. 53-66.

SMITH, M. H., HILlESTAD, H. O., MANLOVE, M. N. \& MARCHINTON, R. L. (1976). Use of population genetics data for the management of fish and wildlife populations. Trans. 41st N. Am. Wildl. Nat. Res. Conf., pp. 119-23.

SMITH, M. H., MANLOVE, M. N., \& JOULE, J. (1978). Spatial and temporal dynamics of the genetic organization of small mammal populations. Pp. 99-113 in Populations of Small Mammals Under Natural Conditions. Pymatuning Laboratory of Ecology Special Publication No. 5, 237 pp.
SOUTHWOOD, T. R. E. (1976). Bionomic strategies and population parameters. Pp. 2648 in Theoretical Ecology: Principles and Applications (Ed. R. M. May). Blackwell Scientific Publications, Oxford, U.K.: viii +317 pp., illustr.

SOUTHWOOD, T. R. E., MAY, R. M., HASSELL, M. P. \& CONWAY, G. R. (1974). Ecological strategies and population parameters. Am. Nat., 108, pp. 791-804.

SPIELMAN, R. S., NEEL, J. V. \& LI, F. H. F. (1977). Inbreeding estimation from population data: models, procedures, and implications. Genetics, 85, pp. 355-71.

SPIESS, E. B. (1977). Genes in Populations. Wiley-Interscience, New York, N.Y.: xi +780 pp., illustr.

TERBORGH, J. (1974). Preservation of natural diversity: the problem of extinction-prone species. BioScience, 24 (12), pp. 715-22.

THORNTON, I. W. B. (1978). White tiger genetics-further evidence. J. Zool., 185, pp. 389-94.

VIDA, G. (1978). Genetic diversity and environmental future. Environmental Conservation, 4(2), pp. 127-32.

WEBSTER, T. P., SELANDER, R. K. \& YANG, S. Y. (1972). Genetic variability and similarity in the Anolis lizards of Bimini. Evolution, 26, pp. 523-35.

WRIGHT, S. (1931). Evolution in mendelian populations. Genetics, 16, pp. 97-159.

WRIGHT, S. (1943). Isolation by distance. Genetics, 28, pp. 114-38.

WRIGHT, S. (1948). On the roles of directed and random changes in gene frequency in the genetics of populations. Evolution, 2, pp. 279-94.

WRIGHT, S. (1951). The genetical structure of populations. Ann. Eugen., 15, pp. 323-54.

WRIGHT, S. (1965). The interpretation of population structure by $F$-statistics with special regard to the systems of mating. Evolution, 19, pp. 395-420.

\title{
WWF Signs Agreement With China
}

The World Wildlife Fund announced recently that it has reached an agreement for cooperation in conservation with the People's Republic of China. The agreement calls for the immediate establishment of a WWF-China Committee of six members - three from WWF International and three from the recently-formed Association for Environmental Sciences of the People's Republic of China. The WWF-China Committee will coordinate links between conservation organizations and authorities in China and WWF world-wide contacts. It will initiate high-priority projects in China and will coordinate action for their implementation.

The agreement was signed by the Vice-Director of the Environment Protection Office of the Chinese State Council, Mr Chu-ge Ping, and the Chairman of WWF International, Sir Peter Scott, who described it as a 'truly historic occasion for world conservation'. Moreover, under new environmental laws passed recently in Beijing (Peking), environmental impact assessment studies are now a compulsory component of all future development planning in China, while two other key conservation decisions by the Chinese Government are as follows:

1. China has agreed to become a State Member of the International Union for Conservation of Nature and Natural Resources (IUCN), the major scientific arm of world conservation, with over 50 sovereign State Members included in its total membership of 450 States, government agencies, and non-governmental organizations from over 100 Nations. IUCN works closely with WWF and [late in 1979 the two organizations moved together into newly-acquired, shared international headquarters near Geneva-as already indicated in Environmental Conservation (Vol. 6, No. 2, p. 110 , Summer 1979). Their address is now as given below].

2. China has agreed immediately to accede to the Convention on International Trade in Endangered Species of Wild Fauna and Flora (CITES). This move is of particular significance as China is one of the major trading Nations in wild plant and animal products.

The Director-General of WWF International said the fact that China had made these commitments and was about to assume a leadership role in conservation may well be considered the most significant single development in conservation since the United Nations Conference on the Human Environment in Stockholm in 1972: 'China, with almost a quarter of the world's population, is facing up to problems which are of crucial importance to Man everywhere in his continuing efforts to achieve a harmonious balance with Nature. This is going to be a two-way street with a full and continuing exchange of information. IUCN/WWF have developed conservation techniques through their work in many countries...., and, by the same token, we have a great deal to learn from the successful conservation measures which have been developed in the People's Republic of China.'

David Mitchell, Director of Public Affairs
World Wildlife Fund
Avenue du Mont Blanc
1196 Gland
Switzerland.

